\title{
OPTIMIZATION OF UPDATING LAND AND BUILDING TAX OBJECT IN IMPROVING LOCAL OWN-SOURCE REVENUE FOR MEDAN DEVELOPMENT ACCELERATION
}

\author{
Elisabet Siahaan ${ }^{1)}$, Khaira Amalia Fachruddin ${ }^{2)}$, Hilma Tamiami Fachruddin ${ }^{3)}$ \\ ${ }^{1)}$ Faculty of Economics and Business, University of Sumatera Utara \\ Email: Dr.Elisabethsiahaan@yahoo.com \\ ${ }^{2)}$ Faculty of Economics and Business, University of Sumatera Utara \\ Email: khaira@usu.ac.id \\ ${ }^{3)}$ Faculty of Engineering, University of Sumatera Utara \\ Email: hilma_tamiami@yahoo.com
}

\begin{abstract}
Abstrak
Pendapatan asli daerah merupakan salah satu sumber pemasukan pemerintah Kota Medan. Pendapatan ini digunakan untuk melakukan percepatan pembangunan Kota Medan, khususnya pada bagian pengembangan infrastruktur. Infrastruktur yang baik akan membantu dalam pelaksanaan operasional usaha yang mendukung peningkatan kesejahteraan masyarakat. Salah satu sumber pendapatan asli daerah adalah penerimaan pajak daerah. Kegiatan pengabdian yang dilakukan berupaya mengoptimalkan pendapatan daerah melalui peningkatan keakuratan nilai objek pajak. Kegiatan pengabdian ini mendukung program rencana jangka menengah pemerintah Kota Medan. Kegiatan pengabdian dilakukan dengan metode pembekalan, workshop, dan pendampingan. Ipteks yang diberikan meliputi etos kerja, komunikasi efektif, teknik pengukuran yang tepat serta penilaian objek pajak. Hasil kegiatan pengabdian ini cukup memuaskan. Terjadi perubahan yang signifikan dari sikap kerja mitra saat melakukan updating data. Hasilnya, masyarakat pemilik objek pajak lebih kooperatif dan updating data berjalan dengan lebih baik.
\end{abstract}

\section{Kata Kunci: Optimisasi Kerja BPPRD, Penilaian Objek PBB, Komunikasi Efektif, Etos Kerja, Pendapatan Daerah}

\begin{abstract}
Local own-source revenue is one of the sources of revenue for the government of Medan. This revenue is used to accelerate the development of the city of Medan, especially in the infrastructure development section. A better infrastructure will help in the implementation of business operations that support the improvement of community welfare. One source of local revenues is the local tax revenue. The community service was conducted to optimize the revenue of Medan through optimizing the value of taxable object. This community service supported the government of Medan medium term plan program. This service was carried out with briefing methods, workshops, and mentorings. Science and technology given include work ethic, effective communication, and taxable object valuation. The results of this community service were satisfactory. There was a significant change in the attitude of partners while updating the data. As the results, the community as the owner of taxable object becomes more cooperative and the updating data goes better.
\end{abstract}

Keywords: BPPRD Work Optimization, L\&B Tax Object Valuation, Effective Communication, Work Ethics, Local Revenue 
Siahaan, E. et al. Optimization Of Updating Land and Building Tax Object In Improving Local Own - Source Revenue...

\section{INTRODUCTION}

\section{Background of Community Service}

The city of Medan has been experiencing a development, especially in the infrastructure sector. The development that itself requires supports from the community to make it run well. One of the supports from the community is to pay taxes as local revenue that will be used for local development (Utarahman et al., 2016). This local revenue is quite important to support the ongoing financing of Medan development, especially in the infrastructure sector. By paying the L\&B tax (Land and Building Tax), the community has actively participated in the development of the city (Directorate General of Taxation, 2012). The greater the $L \& B$ tax received, the more real the development will be. Especially for potential taxpayers or the quite large L\&B tax value. Its role is increasingly greater in financing urban development. If the whole infrastructure and utility of Medan are intended to be achieved well, the efforts must be supported by good tax compliance.

The 2017 local tax compliance program that has been planned before is prepared to motivate the public to be active and willing to pay their taxes, including the Land and Building Tax. This program is aimed at building the culture of the community, "paying taxes is the culture of Medan citizen." If all citizens of Medan are taxcompliant, it is believed that the goals and objectives of urban development can be realized evenly and equitably.

Local Agency Strategy and Policy for Management of Taxes and Levies of Medan is to achieve the optimization of local revenues derived from Local Own-Source Revenue, such as Land and Building Tax. Local Medium Term Development Plan (RPJMD) of Medan also strongly emphasizes the increasing of effectiveness and efficiency of land and building tax revenues that facilitate and support the economic climate in Medan (Medan Government, 2016).

One way to increase the potential of local revenue is from the land and building tax. The Local Tax and Retribution Management Agency (BPPRD) of Medan noted that the realization of local taxes until 29 September 2017 was 72.02 percent or Rp 997.6 billion, 7.4 percent higher than the realization in the same period in 2016, amounting to 64.6 percent. This figure shows that this increase is still not optimal, compared to changes in progress that has taken place in Medan, the potential of the own-source revenue of Medan can be increased through updating the data and the value of the $L \& B$ tax. There are still many taxpayers who pay the L\&B tax based on the extensive conditions of the land and buildings that used to be, even though now it has experienced changes in land area or changes in building area. So it is very necessary for BPPRD to carry out inspections in the field to see and measure directly whether there is a change in the area of land and building of taxpayers. So that the taxpayer pays the $L \& B$ tax according to the area of land and buildings that are in accordance with the actual conditions that occur in the field.

The community service carried out in partnership with BPPRD seeks to help resolve problems in optimizing local revenue through upgrading data and land and building tax values in the city of Medan through mentoring, counseling, and guidance to BPPRD employees. The service team that has expertises in the areas of management, financial management, human resource management, expertises in building architecture, environmental planning, urban planning, expertises in measuring the area of 
Siahaan, E. et al. Optimization Of Updating Land and Building Tax Object In Improving Local Own - Source Revenue...

land and buildings, expertises in assessing land and buildings, and assessing land zones. Consequently, the verification process of data and values runs systematically and appropriately and is able to achieve the optimal optimization of local revenues through the correct L\&B tax.

\section{Partner Problems}

The main source of unacceptable land and building tax revenue received is data inaccuracy and the value held by the Primary tax service office. Assessment of the value of the L\&B tax to date, that is until 2017 has been using the database reference in 2012. Even though around 2012 to 2017 there have been many changes to the object being assessed, for example the possibility of a change in building area and area of land (earth) has occurred, as well as the value of land and buildings from year to year which always increase. There has been no attempt to update the data for now. Data collection is still prioritized on certain objects, not yet done in a mass and comprehensive manner for each object in 21 sub-districts, 151 villages and 2001 environments in Medan.

\section{Solutions Offered}

The community service carried out seeks to build the quality of human resources, namely; ways of working, thinking, and communicating; work characters and work ethics of BPPRD employees so that they become increasingly better and more qualified employees who are finally able to get good and accurate data and values. The development of human resources has many dimensions and linkages. The connection is not only with the interests of BPPRD employees but also related to the interests of employers, the government of Medan and the community. For this reason, a comprehensive arrangement is needed, including developments of human resource, improvements of productivity and work competitiveness, communication skills of field workers who directly communicate with taxpayers,work motivation, work discipline, and honest character, and trustworthy.

\section{IMPLEMENTATION OF COMMUNITY SERVICE}

\section{Service Approach}

The community service program proposed in this proposal wascarried out by conducting learning activities in the form of training, mentoring, and consultation on how to appraise L\&B tax object appropriately, effectively and efficiently. This service implementation program included:

a. Debriefing of science and technology to partner members, head of BPPRD, head of subdivision, and members in charge of updating data

b. Giving workshop on updating data together with MAPPI

c. Assisting the implementation of updating data

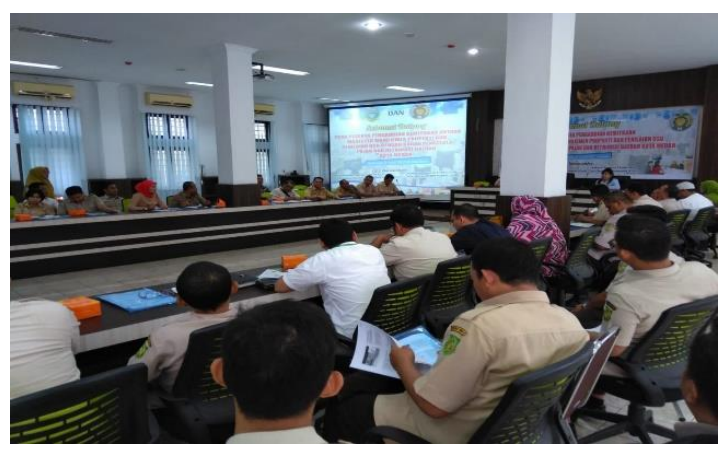

Figure 1. Assistance and Workshop Activities in BPPRD Medan

\section{Awarded Science and Technology}

The science and technology component provided to partners wasrelated to developing the mindset and behavior of partners with their members in carrying out more effective and efficient data 
Siahaan, E. et al. Optimization Of Updating Land and Building Tax Object In Improving Local Own - Source Revenue...

updating activities. Science and technology provided included:

a. Work ethics

It builds the unyielding, responsible, and persistent characters in committing to carrying out the duties and responsibilities assumed by them (Timbuleng and Sumarauw, 2015). This science and technology helped the updating of data from the field officer.

b. Effective communication

Communication is the most important element in social life and interaction with the society (Babatunde, 2015). Effective communication will facilitate the delivery of information (Kelvin-Iloafu, 2016). Trust in the community also increased and could help improve the effectiveness of data updating services.

c. Taxable object valuation

It is related to how to conduct an effective taxable object valuation starting from measurement techniques, estimation techniques of taxable object values, as well as result reports of data collection to the executor.

\section{Partner Contributions}

BPPRD Medan and its members were pro-active during the service process. The debriefing activities and workshops carried out had been enthusiastically followed by partners and members. This was followed seriously by partners and members. This showed how serious BPPRD was in updating the data on L\&B taxobjects listed in its work program. Optimization of tax values would have an impact on the acceleration of the development of Medan.

\section{RESULTS ACHIEVED}

\section{Evaluation on Changes to Partner}

One of the targets of this community service was the change of behavior in the partners related to the given science and technology. In this regard, Table 1 summarizes the changes that occured to partners. Table 1 compares the initial situation with the results of evaluation of community service.

Table 1 Evaluation of Partner Progress

\begin{tabular}{|c|c|c|}
\hline Aspect & Initial Evaluation & Achievement \\
\hline $\begin{array}{l}\text { Work } \\
\text { Ethics }\end{array}$ & $\begin{array}{l}\text { BPPRD employees } \\
\text { in Medan looked } \\
\text { enthusiastic and } \\
\text { hardworking, but } \\
\text { the spirit of work } \\
\text { was still less } \\
\text { reflected in daily } \\
\text { behaviors. } \\
\text { (Enough) }\end{array}$ & $\begin{array}{l}\text { Employees } \\
\text { mastered self- } \\
\text { control and } \\
\text { achieved high } \\
\text { work ethics in } \\
\text { every task } \\
\text { assigned. } \\
\text { (Well) }\end{array}$ \\
\hline $\begin{array}{l}\text { Effect- } \\
\text { ive } \\
\text { Com- } \\
\text { muni- } \\
\text { cation }\end{array}$ & $\begin{array}{l}\text { Effective } \\
\text { communication was } \\
\text { difficult to achieve, } \\
\text { especially when } \\
\text { dealing with the } \\
\text { community. } \\
\text { (Less) }\end{array}$ & $\begin{array}{l}\text { There was a } \\
\text { conducive } \\
\text { atmosphere } \\
\text { between the } \\
\text { community and } \\
\text { BPPRD } \\
\text { especially } \\
\text { through the } \\
\text { delivery of } \\
\text { good } \\
\text { information. } \\
\text { (Well) }\end{array}$ \\
\hline
\end{tabular}


Siahaan, E. et al. Optimization Of Updating Land and Building Tax Object In Improving Local Own - Source Revenue...

\begin{tabular}{|l|l|l|}
\hline Aspect & Initial Evaluation & Achievement \\
\hline $\begin{array}{l}\text { Valua- } \\
\text { tion }\end{array}$ & $\begin{array}{l}\text { Field officers in } \\
\text { the valuation and } \\
\text { updating } r \text { of } \\
\text { the taxable object } \\
\text { database were still } \\
\text { unfamiliar with familiar } \\
\text { were } \\
\text { with effective } \\
\text { valuation } \\
\text { methods, } \\
\text { effective valuation } \\
\text { concepts and } \\
\text { methods alculating the } \\
\text { (Enough) }\end{array}$ & $\begin{array}{l}\text { area of the } \\
\text { a\&B tax object } \\
\text { area. } \\
\text { (Well) }\end{array}$ \\
\hline
\end{tabular}

\section{Changes to Work Ethics}

The service partner looked enthusiastic and hardworking. Even so, many of the partner members were less disciplined in carrying out their duties. This was reflected in the delay in reporting activities carried out by partner members. The work ethic of partner members was less reflected in the execution of daily tasks, apart from the main tasks they carried.

Knowledge of work ethics transferred involved the cultivation of eight elements of the work ethics as a culture that wereinherent in the partner members. The work ethics included the point of view of work as grace, trust, calling, acalization, worship, art, honor, and service. This work ethics were given to partners through debriefing and mentoring.

Field assistance activities for partner members indicated that enthusiasm in carrying out the task of updating data was better. Partner also loved to see the changes that occured to their members. Activity reporting was better and more timely. Partner members considered the task as a responsibility that should be carried out as well as possible for mutual progress.

\section{Changes to Effective Communication}

The interaction between field implementers and the community was an important point in the successful implementation of taxable object database valuation and renewal activities later. Community perceptions of government activities, especially those related to taxation and retribution activities were generally not conducive. This required field workers to have effective work ethics and communication skills to encourage effective participation between the community and renewal of the value of the public taxable object. Effective participation was defined as the cooperative attitude of the community in helping activities to renew the value of the object of tax and retribution so that the community was not harmed from the misjudgment made.

Communication had an important role in facilitating the implementation of data updating activities. Previously, partner often found it difficult to update data due to lack of support from the community. The community service carried out helped to overcome the communication problem.

Effective communication, besides being achieved through communication between the two parties, was also strengthened by the trust of the community. In each data updating activity, field officers were accompanied by the head of village. This was intended as a catalyst to realize effective communication. Evaluation of partner changes indicated that communication had been more effective. The community gave their trust to help the effective data collection process.

\section{Changes to Taxable Object Valuation}

Valuation of the feasibility of the value of the taxable object was a complex process, starting from the calculation of the value of land, building area, to the value of the building. Seminar activities conveyed various methods that could be used in calculating the value of taxable objects as they should in accordance with the 
Siahaan, E. et al. Optimization Of Updating Land and Building Tax Object In Improving Local Own - Source Revenue...

standard of valuation of taxable objects for houses and building land.

The taxable object valuation workshop indicated various potential obstacles that might occur to the implementing officer. Officers were seen as not yet ready to conduct an assessment using scale techniques and applicable building value standards. Limited time was an obstacle in delivering accurate assessing techniques. Special workshops are needed to support the successful absorption of appropriate taxable object valuation in the future.

Behind the difficulties that occured in the absorption of taxable object valuation, participants were seen seriously following the stages of taxable object valuation and wanted to jointly learn to count scale techniques. Workshop participants began to understand the standard of proper valuation techniques in measuring the value of taxable objects, especially on land and building taxable objects.

The implementation of mentoring activities indicated that partner had involved better estimates in determining the extent of taxable objects. Field measurement techniques combined with the calculation of the object area became the basis for determining the evaluation of the value of the taxable object. Valuation in terms of building materials was guided with MMPP.

\section{CONCLUSION AND SUGGESTION}

\section{Conclusions}

The community service that had been carried out concluded:

1. The activity of updating the database of land and building tax (L\&B tax) object value is one of the efforts to increase the efficiency of local revenue that requires work ethics, as well as the seriousness of L\&B tax validation team employees in its implementation so that the objectives of the service can be achieved properly.

2. Effective communication skills are needed in establishing conducive relationships and cooperation with the community. Unfortunately, this capability was not fully owned by field officers who would interact directly with the community. Improvements needed to be made in mastering effective communication.

3. The ability of an effective appraiser based on MAPPI standards is important in helping the success of the valuation program and updating the L\&B tax object value database that will be implemented by BPPRD Medan. Intensive seminars and workshops are needed to achieve a more optimal science and technology transfer.

4. The next obstacle was the lack of HR competency in measuring the extent of tax objects assessed. With the existence of this partnership service, the L\&B tax validation staff in Medan were increasingly aware of accurate tax object measurement techniques so that the value of the taxable object that was set is more appropriate and makes the local own-source revenue increase.

\section{Suggestions}

With reference to the achievements of the community service, it is recommended:

1. Cooperative from the community is very important in the success of the UN database reform program that will be implemented by the BPPRD later, therefore it is strongly recommended to immediately disseminate the information to the public so that the community first understands the existence of these activities. Socialization can be done through print and electronic media, especially through social media.

2. Work ethic, effective communication, and tax measurement and valuation techniques 
Siahaan, E. et al. Optimization Of Updating Land and Building Tax Object In Improving Local Own - Source Revenue...

are important components in the success of database updating activities and optimization of local revenue. The synergy between field officers and the community is the key to program success. It is expected that field officers master and apply the science and technology appropriately.

3. Mentoring and consultation programs will greatly assist the achievement of goals, both devotion activities and successful database updating programs. Therefore it is highly recommended that partners be more proactive in mentoring activities in the future.

\section{ACKNOWLEDGEMENT}

This community service supported by Universitas Sumatera Utara through Lembaga Pengabdian Masyarakat, which provides funding of community service program, which is titled Optimization Of Updating Land and Building Local Own - Source Revenue For Medan Development. In accordance with the Letter of Assignment Agreement, NON PNBP Fiscal Year 2018 No. 173 / UN5.2.3.2.1 / PPM / 2018, April 16, 2018.

\section{REFERENCES}

Babatunde, Osabiya. 2015. Importance of Effective Communication in Public Organisations. Social Science, 3(2), 78-89
Ditjen Pajak. 2012. Pengalihan PBB Menjadi Pajak Daerah, http://www.pajak.go.id/content/seri-pbbpengalihan-pbb-menjadi-pajak-Derah

Kelvin-Iloafu, Lovlyn Ekeowa. 2016. The Role of Effective Communication in Strategic Management of Organizations. International Journal of Humanities and Social Science, 6(12), 93-99

Pemerintah Kota Medan. 2016. Rencana Pembangunan Jangka Menengah (RPJMD) Kota Medan tahun 2016-2021. http://pemkomedan.go.id. Diakses tanggal 2 November 2017

Timbuleng, Stela, dan Jacky Sumarauw. 2015. Etos Kerja, Disiplin Kerja, dan Komitmen Organisasi Pengaruhnya terhadap Kinerja Karyawan pada PT Hasjrat Abadi Cabang Manado. Jurnal EMBA, 3(2), 1051-1060

Utarahman, Nur Riza, Een Walewangko, dan Hanly Siwu. 2016. Analisis Efektivitas dan Kontribusi Penerimaan Pajak Bumi dan Bangunan Perdesaan Perkotaan (PBB-P2P terhadap Pendapatan Asli Daerah (PAD) Kota Tomohon. Jurnal Berkala Ilmiah Efisiensi, 16(2), 267-277 